\title{
Coping with Multitudes
}

\author{
NIDA VASILIAUSKAITE் \\ Department of Philosophy and Cultural Studies, Faculty of Creative Industries, Vilnius Gediminas Technical University, 1 Trakų Street, \\ 01132 Vilnius, Lithuania \\ Email: nida.vasiliauskaite@vgtu.lt
}

\begin{abstract}
This article is an outline of the current issue of Filosofija. Sociologija, thematically divided into four sections. Starting from the most general one, focused on abstract topics of metaphysical kind and big names, proceeding to theorize on practices of human co-existence, then dealing specifically with Marxist paradigm, and finally with problems related to artificial intelligence and digital society. The thought of the 20th century and its socio-political implications up till now unites them all.
\end{abstract}

Keywords: artificial intelligence, hermeneutics, Marxism, ontology, phenomenology, philosophy of law, utopia

How to arrange pieces focused on different objects, made from different perspectives by authors living in different times (despite being contemporaries), so that the whole would be no longer an apparently chaotic mess, but an entity instead? Alive, functional, having structure and separate organs? - This question (internal to any research, any observation, any creativity - any activity of mind) in itself deserves to be considered not purely technically, but rather as a philosophical one: coping with multitudes, squeezing meaning out of coincidences. The present overview of ten articles is a humble place to practice the task.

\section{BEING, KNOWING AND THE SELF}

The first section of the current issue encompasses two papers related by their common interest in ontology, subjectivity and self-perception.

Vladimir Chernus (2021: 5-13) compares the notions of intentionality and 'pure Self' in phenomenological and existential traditions, the later presented by Russian religious thinker Nikolai Berdyaev (1874-1945), who was quite critical to the Husserlian project because of its supposedly bad ontological implications. Chernus takes Berdyaev's side, believing in the possibility to create 'ontology of consciousness' based on his philosophy.

Ilya Inishev, on the other hand, seems to find a satisfying 'ontology of consciousness' in the work of Hans-Georg Gadamer. Dealing with the ontological dimension of hermeneutical experience implied in Gadamer's theory, he prefers the so-called 'strong' reading of Gadamer's points when the transformative power of a hermeneutic event affects not only the self-perception of the interpreting subject, but also his/her body as well as material environments. Inishev goes on presenting Gadamer's concept of the speculative and, in attempt to clarify Gadamer's ideas, proposes his own concept of transubstantiation defined as 'an exchange of performative matter within ordinary acts of perceptual faith' (2021: 20). According to him, 
'transubstantiation' is useful as a model to describe bodily-material dimension of transformative processes, which, in the 'strong' reading, make the core element of hermeneutic ontology.

\section{LAW, NATION AND EDUCATION}

The second section unifies three very different articles on the basis of their somehow practical (in the Aristotelian sense) focus: all are concerned with 'things humans can change', or with social institutions.

Vitaly Ogleznev analyses the nature and potential applications of contextual definitions in modern jurisprudence and philosophy of law (2021: 23-31). He is skeptical about the usefulness of the very distinction between a contextual definition and a genus-differentia definition, widespread in contemporary legal literature due to the impact of analytic philosophy, and develops his argument examining the constitutional legal rules, which can be considered an example of the application of contextual definitions in legal science. According to him, these two types of definition may well coexist in legal language and to an extent even complement each other when different areas of their applicability are taken into account.

Lukáš Perný provides (2021: 32-41) a historico-philosophical reconstruction of utopian concepts in the 19th century's Slovakia formed under the influence of German idealism by local Slovak philosophers (Ján Kollár, Pavol Jozef Šafárik, Ludovít Štúr, Ján Feješ and Štefan Marko Daxner). The utopia under consideration was the sovereign Slovak national state (based on ideas about distinctive 'national character', 'national genius' and the like), sounding almost fantastic at that time, yet becoming reality one hundred years later. Interestingly, Perný takes this particular political success to be the proof of a general point that originally utopian visions can shape political practice (who doubts?).

Spiraling down by the grades of neo-platonic being, Héctor Monarca, Noelia Fernández-González and Ángel Méndez-Núñez investigate even smaller entity than nation or state, depending directly on it: educational policies (2021: 42-50). They offer an epistemological framework to analyse how hegemony is constructed in the field of education, use it to reflect on educational policies since 1980, and defend the thesis that post-structuralism, which up till now dominates debates about education as a system of social accesses, has some neglected negative effects on society. Namely, help to preserve, consolidate and legitimize traditional hierarchies together with the ways to produce and accumulate capital.

\section{MARXIST CONSIDERATIONS}

The last discussed article already breathes Marxism and leads to the third section, intended entirely to it. Bettina Szabados and Aleksandr Sautkin (2021: 51-59) reconstruct the intellectual evolution of Georg Lukács, who, after trying himself as a refined theoretician of art and a fancy social critic, lost his belief in the power of art to mobilize society, turned to Marxism in search for new spiritual guidelines, and later became one of the most influential Marxist thinkers of his time. The authors convincingly show that Lukács had all kinds of religious ideations and understood Lenin's idea of revolution, which fascinated him, in almost Jewish messianic way. That is why he became a Bolshevik and a member of the Communist party, that is why, on the other hand, the Revolution in his own writings acquired an eschatological dimension.

Among other things, Lukács was the first to provide a comprehensive theory of reification, which became the object of the next paper in this section, written by Algirdas Davidavičius, Egidijus Mardosas and Jolita Vvenhardt (2021: 60-68). After some philosophical 
clarifications they aim 'to analyse how successfully the notion of reification is employed for social research (with a special focus on the Lithuanian context) and how this research, in turn, can inform further theoretical development of the notion'. They also have a quite ambitious mission: 'With this article we seek to contribute towards the greater dialogue between social philosophers and empirical researchers', while finding that reification is rather an unpopular concept in actual empirical research today.

\section{ARTIFICIAL INTELLIGENCE}

'Rather, it is the machine which possesses skill and strength in place of the worker, is itself the virtuoso, with a soul of its own in the mechanical laws acting through it; and it consumes coal, oil etc. (matières instrumentales), just as the worker consumes food, to keep up its perpetual motion', Karl Marx wrote in his famous passage on machines (Marx 1973: 614). While Marx generally kept being optimistic on the emancipator power of them, the negative news was also implied by the very lines: 'The worker's activity, reduced to a mere abstraction of activity, is determined and regulated on all sides by the movement of the machinery, and not the opposite' (ibid.) - now it is he who becomes a soulless machine, a thing, moved from outside. Not just the worker - centuries after, any citizen of our increasingly instrumentally rationalized and digitalized society either frequently gets a feeling of being treated in the same way as his mechanical 'colleagues', or tends to see no difference between himself and an automaton.

Alexander Khorin and Ekaterina Voronova speak about drastic social changes and new forms of cognition in a technologically altered world, presuming boldly that from now on 'our reality consists mainly of everyday virtual experiences' (2021: 69). Mostly, they are interested in visual communication and define their goal as 'a philosophical understanding of the impact of visual communication on the transformation of the socio-cultural environment' (ibid:), while I take a risk to doubt their success.

Oksana Chursinova together with Oleksandra Stebelska are more precise in their topic: is the realization of emotional artificial intelligence possible? The paper gives witness to my claim that the condition of incapacity to discern herself from a bio-robot is not only feasible and in a sense popular, but also could be celebrated as something wished and joyous: the authors dwell 'upon the need for a thorough philosophical and methodological analysis of the nature and functions of the human's emotional and sensual sphere in order to identify the possibilities of its implementation by means of artificial intelligence' (2021: 76). The conclusions they draw are rather negative (no, the implementation instead of just simulation of human emotions in any computing system is unlikely currently to happen), but only because of some conceptual mess and contextuality. This means that emotions are not yet understood well enough in order to transmit them on machines properly, the authors generalize sadly.

The last article, by Joaquin Trujillo, elucidates the precise meaning of intelligence in machines. He reviews its different notions common among researchers and developers, compares them to the intelligence of Da-sein rendered hermeneutic-phenomenologically, and concludes on the lines of the later approach: 'It is not the way of intelligence in human being, however. MI does not exist' (2021: 90).

Once again, the question imposes itself: what does it mean to be a human, what is the difference between having intellect and being intellect, finally, what is intellect, and how does it relate (if at all) to the self? Is it prerequisite for an intellect to be alive? Or maybe it is precisely what is dead in us? Once again hermeneutics-phenomenology. The circle ends. 


\section{CONCLUSIONS}

Now, at least, a new living creature, namely, the current Filosofija. Sociologija walks on Earth, pushed into being by imposing a structure on it. Having a head, a body, a tail, and even a shape of uroborous. United also from inside by the thought of the 20th century and its socio-political implications: practical as well as spiritual.

\section{References}

1. Chernus, V. 2021. 'Non-classical Intentionality: An Existential View', Filosofija. Sociologija 32(1): 5-13.

2. Chursinova, O.; Stebelska, O. 2021. 'Is the Realization of the Emotional Artificial Intelligence Possible? Philosophical and Methodological Analysis', Filosofija. Sociologija 32(1): 76-83.

3. Inishev, I. 2021. 'Ordinary Transubstantiations: Gadamer's Notion of "Speculative" and Material Logic of Hermeneutic Experience', Filosofija. Sociologija 32(1): 14-22.

4. Khorin, A.; Voronova, E. 2021. 'The Role of Visuals in the Communication Process', Filosofija. Sociologija 32(1): 69-75.

5. Mardosas, E.; Vveinhardt, J.; Davidavičius, A. 2021. 'Reification in Market Societies: Theoretical Conceptualizations and Researchability', Filosofija. Sociologija 32(1): 60-68.

6. Marx, K. 1973. Grundrisse. Foundations of the Critique of Political Economy (Rough Draft). Penguin Books in association with New Left Review.

7. Monarca, H.; Fernández-González, N.; Méndez-Núñez, A. 2021. 'Social Order, Regimes of Truth and Symbolic Disputes: A Framework to Analyse Educational Policies', Filosofija. Sociologija 32(1): 42-50.

8. Ogleznev, V. 2021. 'The Nature and Potential Applications of Contextual Definition in Philosophy of Law', Filosofija. Sociologija 32(1): 23-31.

9. Perný, L. 2021. 'The Roots of Slovak Utopianism and Utopian Concepts of 1848', Filosofija. Sociologija 32(1): 32-41.

10. Szabados, B.; Sautkin, A. 2021. 'Intellectual Evolution of Georg Lukács in the Context of Developing Lenin's Idea of Revolution', Filosofija. Sociologija 32(1): 51-59.

11. Trujillo, J. 2021. 'The Intelligence of Machines', Filosofija. Sociologija 32(1): 84-92.

\section{NIDA VASILIAUSKAITÉ}

\section{Iveikiant daugi}

\section{Santrauka}

Straipsnyje pristatau naujausią žurnalo Filosofija. Sociologija numerị, kurị tematiškai suskirsčiau ị keturias dalis. Pirmoji skirta bendriausiems abstraktiems filosofiniams klausimams ir klasikams, antroje susitelkiama ị praktinę filosofiją ir prasmingo žmogiško bendrabūvio sąlygas, trečioje praktinę filosofiją specifikuoja marksizmo paradigma, o ketvirtoje nagrinëjama skaitmenine visuomenè ir dirbtinio intelekto samprata. Visus tekstus galop vienaip ar kitaip vienija jų objektas: XX a. mintis ir jos sociopolitinès implikacijos dabarčiai.

Raktažodžiai: dirbtinis intelektas, fenomenologija, hermeneutika, marksizmas, ontologija, teisès filosofija, utopija 